\title{
Roselle Calyces Particle Size Effect on the Physicochemical and Phytochemicals Characteristics
}

\author{
Sandro Cid-Ortega ${ }^{1,2} \&$ José Ángel Guerrero-Beltrán ${ }^{1}$ \\ ${ }^{1}$ Departamento de Ingeniería Química, Alimentos y Ambiental, Universidad de las Américas Puebla, Cholula, \\ Puebla, Mexico \\ ${ }^{2}$ Programa Educativo de Ingeniería en Procesos Alimentarios, Universidad Tecnológica de Izúcar de Matamoros, \\ Izúcar de Matamoros, Puebla, Mexico \\ Correspondence: José Ángel Guerrero-Beltrán, Departamento de Ingeniería Química, Alimentos y Ambiental, \\ Universidad de las Américas Puebla, Cholula, Puebla 72810, Mexico. Tel: 52-222-229-2126. E-mail: \\ angel.guerrero@udlap.mx; joseangel150@hotmail.com
}

Received: June10, 2014 Accepted: July 9, 2014 Online Published: July 12, 2014

doi:10.5539/jfr.v3n5p83 URL: http://dx.doi.org/10.5539/jfr.v3n5p83

\begin{abstract}
The effect of average particle size (APS), type of solvent, and extraction times (ET) on the physicochemical (moisture, $\mathrm{pH}$, total soluble solids (TSS), titratable acidity, color, water activity $\left(a_{w}\right)$, density), and phytochemical (total anthocyanins and phenols content)propertiesin Hibiscus sabdariffa (Roselle) calyces was analyzed. The phytochemical properties evaluation was performed using a factorial design $2 \times 3 \times 3$ : two APS (median diameters, $\mathrm{d}_{50}$, of $0.55 \pm 0.016$ (fine powder) and $0.97 \pm 0.034$ (ground powder) $\mathrm{mm}$ ), three solvents (water, $2 \%$ citric acid, and $50 \%$ ethanol) and three ET $(30,45$, and $60 \mathrm{~min})$. All extractions were performed at $50{ }^{\circ} \mathrm{C}$. The APS was determined by sieve analysis using Tyler sieves of different number of mesh. Regarding physicochemical properties, no significant differences $(\mathrm{p}>0.05)$ were observed in moisture content, $\mathrm{pH}$, and titratable acidity; however, the $0.55 \mathrm{~mm}$ fine powder (FP) of Hibiscus calyces had lower $a_{w}(0.37 \pm 0.01)$ and higher TSS $(5.53 \pm 0.05 \%)$ than the $0.97 \mathrm{~mm}$ ground powder (GP). The extracts obtained fromGP showed a deeper red color than those of FP. The best combination of independent variables, in order to obtain the highest concentration of anthocyanins $(451.4 \pm 28.1 \mathrm{mg} / 100 \mathrm{~g}$ d.s. $)$ and total phenols $(2016.2 \pm 159.8 \mathrm{mg} / 100 \mathrm{~g}$ d.s. $)$ were APS of $0.55 \mathrm{~mm}$, $50 \%$ ethanol, and ETof 30 min.
\end{abstract}

Keywords: Hibiscus sabdariffa, average particle size, phytochemicals, anthocyanins, phenolic compounds

\section{Introduction}

Roselle, also known as sorrel, Jamaica flower, and karkade, has been used by people for preparing soft drinks and in traditional medicine. It has been observed that its components, such as vitamins (C \& E), polyphenol acidsand flavonoids, mainly anthocyanins, have functional properties. The Roselle calyces production, in developing countries, is of great importance since its production represents a very important income for people from rural communities (Juliani et al., 2009). Today, several studies have shown that compounds found in aqueous and ethanol Roselle calyces extracts may have antioxidant properties (Josiah et al., 2010). These compounds could work in several ways in humans; for instance, they could have anticancer characteristics (Akim, Chooi, Rahmat, \& Amiruddin, 2011). They may also reduce chronic diseases such as diabetes mellitus (Sini, Umar, \& Inuwa, 2011), dyslipidemias (Ubani, Joshua, \& Oraeki, 2010), hypertension (Herrera-Arellano, Miranda-Sánchez, \& Avila-Castro, 2007; Ojeda et al., 2010) and cardiovascular diseases, among others. Some of these compounds (flavonoids and anthocyanins) are natural which have no toxic or mutagenic effects (Ali, Wabel, \& Blunden, 2005; Fakeye, 2008).

Particle size of powdered materials is an essential part of their characterization. This is closely linked to the behavior of the material and/or its physicochemical properties (Guerrero-Beltrán, Jiménez-Munguía, Welti-Chanes, \& Barbosa-Cánovas, 2009). Therefore, the average particle size, the extraction temperature, the type of solvent, and the solid-solvent ratio have a significant impact on the extraction of bioactive compounds of parts of plants. It has been shown that the yields of anthocyanins, by extraction with solvents, increases as the particle size of Roselle calyces decreases (Cissé et al., 2012). Also, the increase of the solid-solvent ratio improves the yields of phenolic compounds in the extract (Dai \& Mumper, 2010). Another important factor is the 
temperature of extraction. It has been found that increasing the temperature for extraction, up to $80^{\circ} \mathrm{C}$, increases the yields of total phenols in soy extracts using soy powder with an average particle size of $0.459 \mathrm{~mm}$ (Jokić et al., 2010). However, the use of temperatures higher than $70{ }^{\circ} \mathrm{C}$ for prolonged periods may cause significant degradation of anthocyanins (Cissé, Vaillant, Acosta, Dhuique-Mayer, \& Dornier, 2009; Gartaula \& Karki, 2010).

The aim of this study was to determine the effect of the average particle size, type of solvent and extraction time on the physicochemical and phytochemical contents in Roselle calyces.

\section{Materials and Methods}

\subsection{Roselle Calyces}

Creole Roselle calyces (long red variety) from Chiautla de Tapia, Puebla, Mexico, were usedin the study. Roselle calyces fine powder (FP) was obtained using a stainless steel Spray Veyco MPV mill model 100 (Mexico) with a mesh of $0.5 \mathrm{~mm}$. Roselle calyces ground powder (GP) was obtained using an industrial JR blender model LM-12 (Mexico) of $12 \mathrm{~L}$ of capacity. Roselle calyces powders were analyzed for their physicochemical (average particle size, moisture, $\mathrm{pH}$, water activity, total soluble solids, titratable acidity, color, tap density) and phytochemical (total anthocyanins and phenols content) properties.

\subsection{Average Particle Size}

The APS was performed using a Tyler Ro-Tap ${ }^{\circledR}$ RX-812 (Mentor, OH, USA) sifter with different meshes (2, 1.4, $1.0,0.85,0.6,0.5,0.425,0.3,0.25$ and $0.125 \mathrm{~mm}$ ). At the bottom of the column of sieves, a dish to collect fines was placed (Gee \& Or, 2002). Sieving tests were performed for different times $(5,6,7,8,9$, and $10 \mathrm{~min}$ ) for establishing the most suitable sieving time. $50 \mathrm{~g}$ of sample was used; then, powders retained in each sieve were weighed. From this information, the size distribution and cumulative weight curves were plotted as well as the mean diameter, $\mathrm{d}_{50}$ (O’Hagan, Hasapidis, Coder, Helsing, \& Pokrajac, 2005; Guerrero-Beltrán, Jiménez-Munguía, Welti-Chanes, \& Barbosa-Cánovas, 2009).

\subsection{Physicochemical Properties}

\subsubsection{Moisture Content}

It was measured according to the Mexican Official Standard NOM-116-SSA1-1994. Sample was dehydrated at $100{ }^{\circ} \mathrm{C}$ for 4 hours in a HDP-334 MAPSA oven (Grupo Rocas, S.A., Monterrey, NL, Mexico) at atmospheric pressure.

\subsubsection{Titratable Acidity}

It was assessed according to 22.061 AOAC (1980) method. One g of sample was weighed and placed in a 100 $\mathrm{mL}$ glass beaker. Forty milliliters of distilled water were added, heated to reach $70{ }^{\circ} \mathrm{C}$, and let stand for 1 hour. The supernatant was filtered through Whatman paper No. 4. The Roselle residues were rinsed with two portions of $20 \mathrm{~mL}$ of hot distilled water. The filtrate and the washings were transferred to a $100 \mathrm{~mL}$ flask, cooled down to room temperature, brought to volume and thoroughly mixed. An aliquot of $25 \mathrm{~mL}$ of the extract was titrated with $0.1 \mathrm{~N} \mathrm{NaOH}$ until reaching $\mathrm{pH}$ 8.3. Results are reported as $\mathrm{g}$ of malic acid per $100 \mathrm{~g}$ of calyces.

\subsubsection{Total Soluble Solids (TSS)}

An extract was obtained by mixing $10 \mathrm{~g}$ of Roselle calyces powder with $100 \mathrm{~mL}$ of distilled water. This blend was allowed to stand for 1 hour at room temperature and stirring manually sporadically. Total soluble solids were determined according to 31.011 AOAC (1980) method, using an Atago refractometer (Atago Co. LTD, Tokyo, Japan) model Master-M (range of $0-32^{\circ} \mathrm{Bx}$ ). For correcting reading at $20{ }^{\circ} \mathrm{C}$, a set of tables, found in the Mexican Standard NMX-FF-015- 1982, were used.

\section{$2.3 .4 \mathrm{pH}$}

It was performed according to 10.035 AOAC (1980) method with some modifications (Mexican Standard NMX-F-317, 1978).Five g of Roselle powders were added with $10 \mathrm{~mL}$ of distilled water and mixed until getting a uniform paste, an electrode was submerged directly in the sample. An Orion pHmeter model 420A (Orion Research Inc. Jacksonville, FL, USA) was calibrated with buffer solutions of $\mathrm{pH}$ 4, 7, and 10.

\subsubsection{Color}

A Colorgard system 05 colorimeter (Gardner, Germany) was used in the reflectance mode. For color determination, the colorimeter was previously calibrated using black and white mosaics. For the entire Roselle calyces a plate with anillumination gap of $3.7 \mathrm{~cm}$ in diameter was used. Two calyces were placed in a Petri dish of $9.44 \mathrm{~cm}$ in diameter. Regarding fine and ground powders, a plate with anilluminationgap of $1.9 \mathrm{~cm}$ in 
diameter was used. The Roselle samples were placed in a $50 \mathrm{~mL}$ beaker until reaching the $20 \mathrm{~mL}$ mark (about 16.3 and $9.2 \mathrm{~g}$ of fine and ground powders, respectively). For extracts, obtained according to the TSS method, the transmittance was measured placing $20 \mathrm{~mL}$ of sample in a quartz cell (BYK-Gardner U $10.0 \mathrm{~mm}$ ). Color parameters were measured in the CIELab scale: $L^{*}$ (lightness, $0-100$ ), $a^{*}$ (green to red) and $b^{*}$ (blue to yellow). From these data, purity $(C$, color saturation) and hue $(H)$ were calculated according to the follow equations:

$$
\begin{aligned}
& C=\left(a^{* 2}+b^{* 2}\right)^{1 / 2} \\
& H=\tan ^{-1}\left(b^{*} / a^{*}\right)
\end{aligned}
$$

\subsubsection{Water Activity $\left(a_{w}\right)$}

It was measured using an AQUA-LAB hygrometer model 4TE (Decagon Devices Inc., Pullman, Washington, USA). The equipment was calibrated with standard solutions of $6.0 \mathrm{M} \mathrm{NaCl}\left(a_{w}=0.76 \pm 0.003\right)$ and $8.57 \mathrm{M} \mathrm{LiCl}$ $\left(a_{w}=0.50 \pm 0.003\right)$ at $25 \pm 0.2^{\circ} \mathrm{C}$ (Decagon Devices Inc., 2008).

\subsubsection{Density}

It was performed according to the 962.37 AOAC (1995) method. For liquid extracts, picnometers of $25 \mathrm{~mL}$ were used. For fine and ground powders of Roselle calyces, Grease picnometers were used. Empty $\left(\mathrm{W}_{1}\right)$, filled with distilled water $\left(\mathrm{W}_{2}\right)$, and filled with sample $\left(\mathrm{W}_{3}\right)$ picnometers were weighed. The density $\left(25^{\circ} \mathrm{C}\right)$ was calculated according to the following equation:

$$
\rho=\left[\left(W_{2}-W_{l}\right) /\left(W_{3}-W_{1}\right)\right] * \rho H_{2} O
$$

where $\rho(\mathrm{g} / \mathrm{mL})$ is the density of sample and $\rho \mathrm{H}_{2} \mathrm{O}(\mathrm{g} / \mathrm{mL})$ is the density of water at $25^{\circ} \mathrm{C}$.

\subsection{Phytochemical Properties}

\subsubsection{Extracts}

A $2 \times 3 \times 3$ factorial design was used: two average particle sizes (fine and ground powders), three types of solvents (distilled water, $2 \%$ citric acid, and 50\% ethanol), and three extraction times (30, 45, and $60 \mathrm{~min}$ ). Extractions were performed at $50^{\circ} \mathrm{C}$ at a Roselle:solvent ratio of 1:10according to the Chumsri, Sirichote, and Itharat (2008) method. Mixtures were filtered through Whatman paper No. 4, placed in vials of $40 \mathrm{~mL}$ and covered with aluminum foil.

\subsubsection{Total Anthocyanins Content (TAC)}

It was performed according to the Lee, Durst, and Wrolstad (2005) method. One mL of Roselle extract was diluted to $10 \mathrm{~mL}$ with distilled water. Therefore, one $\mathrm{mL}$ of this solution was diluted to $5 \mathrm{~mL}$ with buffer $\mathrm{pH} 1.0$ into test tubes (wrapped with aluminum foil). Another milliliter of the Roselle solution was diluted to $5 \mathrm{~mL}$ with buffer $\mathrm{pH}$ 4.5. Mixtures were allowed to stand for $30 \mathrm{~min}$ at room temperature and then absorbances measured, at 520 and $700 \mathrm{~nm}$, using a Cary 100 UV-visible spectrophotometer (Varian Inc., Palo Alto, CA, USA), in $4 \mathrm{~mL}$ spectrophotometer glass cells. Results were expressed as equivalents of cyanidin-3-glucoside per $100 \mathrm{~g}$ of Roselle calyces, according to the following equation:

$$
C A=\left(A^{*} M W^{*} D F^{*} V^{*} 100\right) /\left(\varepsilon^{*} L^{*} w\right)
$$

where $C A$ is the concentration of anthocyanins $(\mathrm{mg} / 100 \mathrm{~g}), A$ is the absorbance difference $\left(A=\left[\mathrm{A}_{520 \mathrm{~nm}}-\mathrm{A}_{700 \mathrm{~nm}}\right]_{\mathrm{pH}=1.0}-\left[\mathrm{A}_{520 \mathrm{~mm}}-\mathrm{A}_{700 \mathrm{~nm}}\right]_{\mathrm{pH}=4.5}\right), M W$ is the molecular weight of cyanidin-3-glucoside (449.2 $\mathrm{g} / \mathrm{mole}), D F$ is the dilution factor, $V$ is the total volume of extract $(\mathrm{mL}), w$ is the weight of the sample used in the extraction $(\mathrm{g}), L$ is the cell width $(1 \mathrm{~cm}), \varepsilon$ is the coefficient of molar extinction for cyanidin-3-glucoside $(26,900$ $\mathrm{L} / \mathrm{mole}-\mathrm{cm}$ ), and 100 is the conversion factor for obtaining $\mathrm{mg} / 100 \mathrm{~g}$ of sample.

\subsubsection{Total Phenols Content}

It was determined by the spectrophotometric Folin and Ciocalteu method (Singleton \& Rossi, 1965). Three mL of distilled water, $15 \mu \mathrm{L}$ of the extract, and $250 \mu \mathrm{L}$ of the Folin and Ciocalteu reagent were placed in test tubes (wrapped with aluminum foil). Samples were mixed and let stand for up to 8 minutes before adding $750 \mu \mathrm{L}$ of $20 \% \mathrm{Na}_{2} \mathrm{CO}_{3}$. Then, distilled water was added to make up $5 \mathrm{~mL}$, totally mixed, and allowed to stand for 2 hours at room temperature $\left(26 \pm 1{ }^{\circ} \mathrm{C}\right)$ in the darkness. The absorbance was measured at $765 \mathrm{~nm}$ using a Cary 100 UV-visible spectrophotometer (Varian Inc., Palo Alto, CA, USA). Various standard curves were performed with different concentrations of Gallic acid (GA) (Sigma, St. Louis, MO, USA): $0,0.008 \pm 0.001,0.016 \pm 0.001$, $0.024 \pm 0.002,0.032 \pm 0.003,0.040 \pm 0.004,0.048 \pm 0.004,0.056 \pm 0.005$, and $0.064 \pm 0.006 \mathrm{mg}$. The average standard curve was: Abs $=21.014 \pm 0.810(1 / \mathrm{mg} \mathrm{GA}) * \mathrm{X}(\mathrm{mg} \mathrm{GA})+0.025 \pm 0.006, \mathrm{R}^{2}=0.998 \pm 0.001$. Results were expressed as Gallic acid equivalents per $100 \mathrm{~g}$ of Roselle calyces. 


\subsection{Statistic Analysis}

The effect of the average particle size, on the physicochemical properties of Roselle calyces, was performed by analysis of unpaired t test with a significance level of 0.05 . Regarding to the phytochemical properties, a multivariate analysis and a Tukey's multiple comparison tests were applied to compare the differences within averages. Differences were considered significant for values of $p \leq 0.05$.

\section{Results and Discussion}

\subsection{Granulometry}

According to the sieving preliminary tests, performed for different times, it was observed that the best time for sieving was 7 minutes. Figure 1 depicts the weight of powder retained on each mesh. The greater weight of fine Roselle calyces powder was retained in the sieve of $0.6 \mathrm{~mm}(57.13 \pm 2.42 \%)$ and the ground Roselle calyces powder was retained in the sieve of $1.0(25.45 \pm 1.3 \%)$ and $1.4(30.16 \pm 2.46 \%) \mathrm{mm}$. The cumulative weight curves of retained powders are also shown in Figure 2. From this curve, the median diameter $\left(\mathrm{d}_{50}\right)$ was obtained by interpolation; the $\mathrm{d}_{50}$ values were $0.55 \pm 0.016$ and $0.97 \pm 0.034 \mathrm{~mm}$ for fine and ground Roselle calyces powders, respectively.

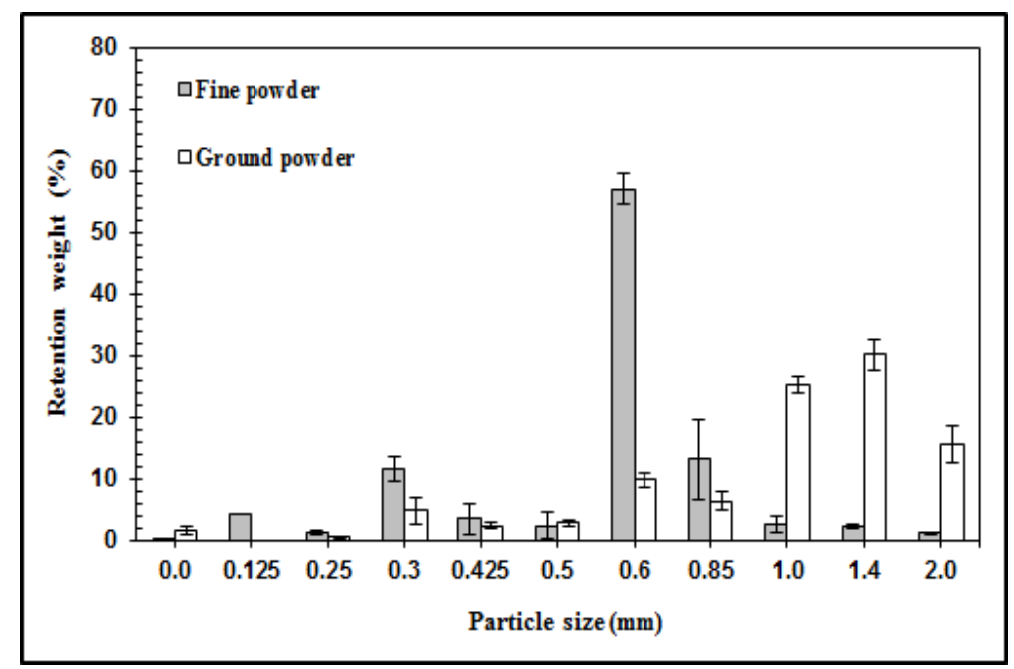

Figure 1. Particle size distribution for fineand ground Roselle calyces powders. Values represent the mean \pm standard deviation $(\mathrm{n}=3)$

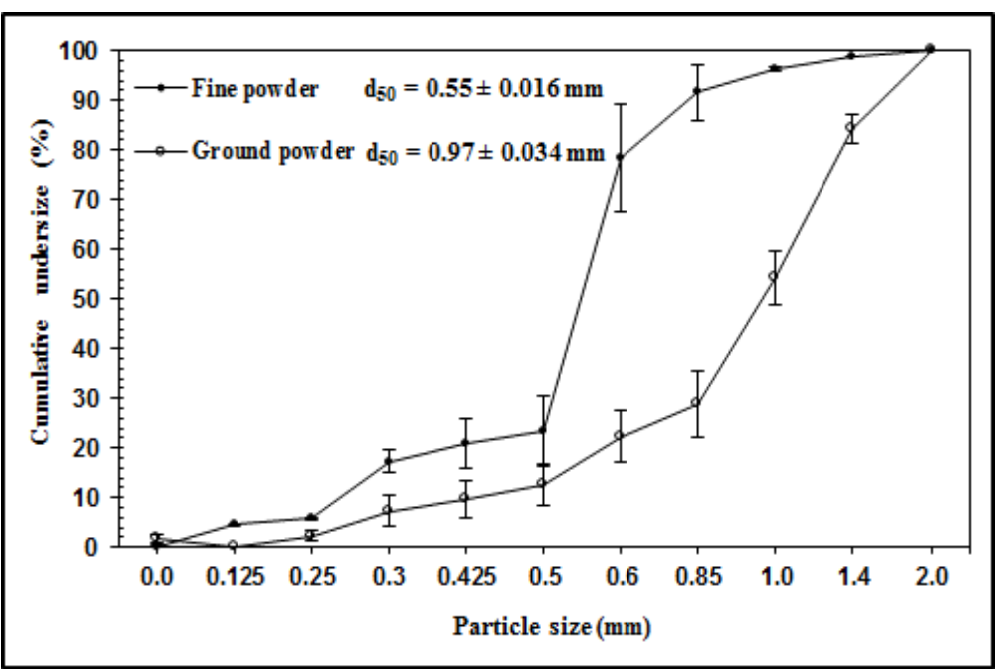

Figure 2. Particle size cumulative weight for fine and ground Roselle calyces powders. Values represent the mean \pm standard deviation $(\mathrm{n}=3)$ 


\subsection{Physicochemical Characteristics}

The effect of the average particle size on the physicochemical characteristics of Roselle calyces is shown in Table 1. The moisture content and $\mathrm{pH}$ of Roselle are within the range recommended by the Mexican Standard NMX-FF-115-SCFI-2010 (a maximum of $12 \%$ of moisture and $\mathrm{pH} 3$ ). Significant differences $(\mathrm{p} \leq 0.05$ ) were observed only in total soluble solids and water activity. Extracts obtained using fine powder $(0.5 \mathrm{~mm})$ had higher content of TSS and lower $a_{w}$ in contrast with those from ground powder $(1.0 \mathrm{~mm})$. By having a smaller average particle size, there is more contact surface with the solvent; therefore, there is a much more efficient extraction comparing to a greater average particle size.

Table 1. Effect of average particle size on the physicochemical characteristics of Roselle calyces

\begin{tabular}{lll}
\hline & \multicolumn{2}{l}{ Average particle size } \\
\cline { 2 - 3 } Characteristic & $0.5 \mathrm{~mm}$ & $1.0 \mathrm{~mm}$ \\
\hline Moisture content $(\mathrm{g} / 100 \mathrm{~g})$ & $9.18 \pm 0.52 \mathrm{a}$ & $9.25 \pm 0.47 \mathrm{a}$ \\
$\mathrm{pH}\left(23.8 \pm 3.2^{\circ} \mathrm{C}\right)$ & $2.27 \pm 0.12 \mathrm{a}$ & $2.16 \pm 0.05 \mathrm{a}$ \\
Water activity $\left(25 \pm 0.02^{\circ} \mathrm{C}\right)$ & $0.37 \pm 0.01 \mathrm{a}$ & $0.43 \pm 0.00 \mathrm{~b}$ \\
Total soluble solids $(\%)\left(20^{\circ} \mathrm{C}\right)$ & $5.53 \pm 0.05 \mathrm{a}$ & $5.09 \pm 0.26 \mathrm{~b}$ \\
Titratable acidity as $\mathrm{malic}$ acid $(\mathrm{g} / 100 \mathrm{~g})$ & $20.13 \pm 0.77 \mathrm{a}$ & $20.45 \pm 0.70 \mathrm{a}$ \\
Density of extracts $(\mathrm{mg} / \mathrm{mL})\left(22^{\circ} \mathrm{C}\right)$ & $1017.11 \pm 1.11 \mathrm{a}$ & $1013.66 \pm 5.30 \mathrm{a}$ \\
Tap density $(\mathrm{mg} / \mathrm{mL})\left(25^{\circ} \mathrm{C}\right)$ & $800.23 \pm 31.3 \mathrm{a}$ & $470.95 \pm 27.0 \mathrm{~b}$ \\
\hline
\end{tabular}

Values represent the mean \pm standard deviation $(\mathrm{n}=5)$. Values that are followed by different letters within the same row are significantly different $(\mathrm{p}<0.05)$. ${ }^{\mathrm{a}}$ Extracts obtained at a ratio of 1:10 of Roselle:water for $60 \mathrm{~min}$.

Suliman, Ali, Idriss-Sharaf, and Abdualrahman (2011) reported a TSS content of 5 and $5.5 \%$ in red and white Roselle calyces, respectively. The high acidity in the Roselle calyces extracts is given by organic acids such as citric, malic, tartaric, hibiscus, succinic, oxalic, and ascorbic acids. Cañigueral (2003) reported an acidity between 15 and $30 \%$ in Roselle calyces (citric, malic, tartaric, and hibiscus acids). Galicia-Flores, Salinas-Moreno, Espinoza-García, \& Sánchez-Feria (2008) reported an acidity (as malic acid) of 15.8, 19.6 and $18.7 \%$ and $\mathrm{pH}$ of $2.55,2.36$, and 2.15 for samples from Sudan, China and Mexico, respectively. $\mathrm{pH}$ values are similar to those obtained in this work as well as the acidity of Roselle calyces from China.Chumsri, Sirichote, \& Itharat (2008)reported higher $\mathrm{pH}(2.86 \pm 0.02)$ and lower acidity $(1.85 \pm 0.05 \%$ malic acid $)$ than values obtained in this work; however, the TSS content was similar $(5.33 \pm 0.16 \%)$. For density, powders with different particle size showed very different values, having higher density the fine powder than the ground powder.

\subsection{Color Properties}

Table 2 shows color parameters of Roselle calyces powders with different particle size. The Roselle calyces ground powder had higher tone and lower purity than fine powder and whole calyces $(\mathrm{p} \leq 0.05)$; this indicates that the ground powder had a less intense red color. Galicia-Flores et al. (2008) reported similar results about tone (13.8) for ground Roselle calyces from Guerrero, Mexico; however, their lightness (42.1) and purity (31.8) were different to that obtained in this study. Abou-Arab et al. (2011) reported different color parameter values for Roselle calyces $\left(L^{*}=28.3 \pm 1.0, a^{*}=71.0 \pm 2.0, b^{*}=45.9 \pm 2.0\right)$ to those obtained in this study. Furthermore, the extracts obtained from ground powder $(1.0 \mathrm{~mm})$ showed higher purity (redder) than those of fine powder $(0.5$ $\mathrm{mm})$; however, no significant differences $(\mathrm{p}>0.05)$ in tone were observed (Table 3$)$. Similar results were reported by Salazar-González, Vergara-Balderas, Ortega-Regules, and Guerrero-Beltrán (2012) in aqueous extracts of calyces using the same Roselle:water ratio (1:10) and same variety of Roselle $(L=22.83 \pm 0.14, a=$ $45.61 \pm 0.08, b=13.59 \pm 0.11, H=16.59 \pm 0.00$, and $C=47.59 \pm 0.11)$. Chumsri et al. (2008) reported values of $L^{*}$, a*, and $b^{*}$ of $0.75 \pm 0.16,5.22 \pm 1.16$, and $1.24 \pm 0.27$, respectively, for Roselle calyces (from Sudan) extracts using a calyces:water ratio of $1: 10$ and heating at $60{ }^{\circ} \mathrm{C}$ for $60 \mathrm{~min}$. They only mention that calyces were ground using a grinder. Differences in color parameter values could be due to the variety of Roselle calyces, the method of extraction, and the average particle size. 
Table 2. Effect of particle size on color parameters of Roselle calyces powders

\begin{tabular}{llll}
\hline & \multicolumn{3}{c}{ Average particle size } \\
\cline { 2 - 3 } Parameter & $0.5 \mathrm{~mm}$ & $1.0 \mathrm{~mm}$ & Whole \\
\hline$L^{*}$ & $38.37 \pm 0.20 \mathrm{a}$ & $31.06 \pm 2.40 \mathrm{~b}$ & $13.89 \pm 1.92 \mathrm{c}$ \\
$a^{*}$ & $22.76 \pm 0.30 \mathrm{a}$ & $17.48 \pm 2.15 \mathrm{~b}$ & $25.65 \pm 1.34 \mathrm{c}$ \\
$b^{*}$ & $6.53 \pm 0.14 \mathrm{a}$ & $5.55 \pm 0.56 \mathrm{~b}$ & $6.95 \pm 0.52 \mathrm{a}$ \\
Hue (H) & $15.99 \pm 0.22 \mathrm{a}$ & $17.65 \pm 0.48 \mathrm{~b}$ & $15.18 \pm 1.22 \mathrm{a}$ \\
Purity (C) & $23.68 \pm 0.32 \mathrm{a}$ & $18.34 \pm 2.22 \mathrm{~b}$ & $26.58 \pm 1.32 \mathrm{a}$ \\
\hline
\end{tabular}

Values represent the mean \pm standard deviation $(n=5)$. Values that are followed by different letters within the same row are significantly different $(\mathrm{p} \leq 0.05)$.

Table 3. Effect of average particle size in color properties of Roselle calyces extracts

\begin{tabular}{lll}
\hline & \multicolumn{2}{c}{ Average particle size } \\
\cline { 2 - 3 } Parameter & $0.5 \mathrm{~mm}$ & $1.0 \mathrm{~mm}$ \\
\hline$L^{*}$ & $20.08 \pm 0.42 \mathrm{a}$ & $22.50 \pm 1.00 \mathrm{~b}$ \\
$a^{*}$ & $44.21 \pm 0.75 \mathrm{a}$ & $49.86 \pm 1.70 \mathrm{~b}$ \\
$b^{*}$ & $10.98 \pm 0.21 \mathrm{a}$ & $12.47 \pm 0.69 \mathrm{~b}$ \\
Hue (H) & $13.94 \pm 0.06 \mathrm{a}$ & $14.03 \pm 0.32 \mathrm{a}$ \\
Purity (C) & $45.55 \pm 0.77 \mathrm{a}$ & $51.40 \pm 1.81 \mathrm{~b}$ \\
\hline
\end{tabular}

Values represent the mean \pm standard deviation $(n=5)$. Values that are followed by different letters within the same row are significantly different $(\mathrm{p} \leq 0.05)$.

3.4 Phytochemicals Content in Roselle Calyces

The results of the phytochemicals of Roselle calyces are shown in Table 4. 
Table 4. Effect of average particle size (APS), solvent type (ST), and extraction times (ET) on the phytochemical properties of Roselle calyces

\begin{tabular}{|c|c|c|c|c|}
\hline \multirow[b]{2}{*}{ APS } & \multirow[b]{2}{*}{ ST } & \multirow[b]{2}{*}{$\mathrm{ET}(\min )$} & $\mathrm{TMA}^{\mathrm{a}}$ & $\mathrm{TP}^{\mathrm{b}}$ \\
\hline & & & \multicolumn{2}{|c|}{ (mg/100 g of Roselle calyces) } \\
\hline \multirow{9}{*}{$0.5 \mathrm{~mm}$} & \multirow{3}{*}{ Ethanol $(50 \%)$} & 30 & $451.4 \pm 28.1_{\mathrm{a}}$ & $2016.2 \pm 159.8_{a}$ \\
\hline & & 45 & $447.3 \pm 22.6_{a}$ & $1918.5 \pm 203.3_{\mathrm{a}}$ \\
\hline & & 60 & $432.3 \pm 18.1_{\mathrm{a}}$ & $1804.5 \pm 202.8_{\mathrm{ad}}$ \\
\hline & \multirow{3}{*}{ Distilled water } & 30 & $274.1 \pm 12.9_{\mathrm{ef}}$ & $1252.4 \pm 98.1_{\mathrm{cg}}$ \\
\hline & & 45 & $260.9 \pm 6.8_{\mathrm{egk}}$ & $973.9 \pm 93.4_{f}$ \\
\hline & & 60 & $259.1 \pm 23.1_{\mathrm{eh}}$ & $1187.5 \pm 74.7_{\mathrm{bfgh}}$ \\
\hline & \multirow{3}{*}{ Citric acid (2\%) } & 30 & $299.8 \pm 5.1_{\mathrm{dfm}}$ & $1250.1 \pm 126.0_{\mathrm{chi}}$ \\
\hline & & 45 & $274.6 \pm 12.9_{\text {ejlm }}$ & $1099.8 \pm 102.0_{\mathrm{bgi}}$ \\
\hline & & 60 & $265.3 \pm 21.3_{\mathrm{ej} l n}$ & $1047.8 \pm 149.6_{\mathrm{bgi}}$ \\
\hline \multirow{9}{*}{$1.0 \mathrm{~mm}$} & \multirow{3}{*}{ Ethanol $(50 \%)$} & 30 & $321.5 \pm 19.9_{\mathrm{bd}}$ & $1491.1 \pm 75.9_{\mathrm{ce}}$ \\
\hline & & 45 & $350.5 \pm 24.7_{\mathrm{bc}}$ & $1582.2 \pm 175.4_{\mathrm{de}}$ \\
\hline & & 60 & $364.6 \pm 8.4_{c}$ & $1628.8 \pm 139.0_{\mathrm{de}}$ \\
\hline & \multirow{3}{*}{ Distilled water } & 30 & $282.4 \pm 12.5_{\mathrm{ei}}$ & $1224.0 \pm 32.8_{\mathrm{bgi}}$ \\
\hline & & 45 & $294.1 \pm 9.5_{\text {dfgij }}$ & $1266.7 \pm 52.0_{\text {chi }}$ \\
\hline & & 60 & $297.9 \pm 8.0_{\mathrm{dfl}}$ & $1252.1 \pm 111.0_{\text {chi }}$ \\
\hline & \multirow{3}{*}{ Citric acid $(2 \%)$} & 30 & $284.2 \pm 13.5_{\mathrm{ej} l \mathrm{~m}}$ & $1247.7 \pm 83.8_{\text {chi }}$ \\
\hline & & 45 & $253.2 \pm 9.3_{\mathrm{en}}$ & $1064.7 \pm 89.1_{\text {bgfi }}$ \\
\hline & & 60 & $238.1 \pm 15.8_{\mathrm{hkn}}$ & $1069.0 \pm 96.0_{\text {bgfi }}$ \\
\hline
\end{tabular}

Values represent the mean \pm standard deviation $(n=6)$. Values bearing different letters in the same column are significantly different $(\mathrm{p} \leq 0.05)$. ${ }^{\mathrm{a}} \mathrm{TMA}$ : total monomeric anthocyanins, expressed as mg equivalents of cyanidin-3-glucoside. ${ }^{\mathrm{b}}$ TP: total phenols, expressed as mg equivalents of Gallic acid.

\subsubsection{Total Anthocyanins Content (TAC)}

The highest concentration of anthocyanins was obtained using $50 \%$ ethanol and an average particle size of 0.5 $\mathrm{mm}$. The extraction time was not statistically different $(\mathrm{p}>0.05)$. A negative correlation $\left(\mathrm{R}^{2}=0.9904\right)$ was observed between concentration of anthocyanins and the extraction time; as time of extraction increased, the anthocyanins content decreased showing overall averages of $318.9 \pm 64.0,313.4 \pm 70.3$, and $309.5 \pm 70.8$ $\mathrm{mg} / 100 \mathrm{~g}$ of calyces for extraction times of 30,45 , and $60 \mathrm{~min}$, respectively. This tendency was observed in most of the treatments except for the extracts with $50 \%$ ethanol and distilled water using an APS of $1.0 \mathrm{~mm}$. The anthocyanins degradation by temperature may be due to interaction of anthocyanins with sugars and proteins, originating by the Maillard reaction (Tonon, Brabet, \& Hubinger, 2010). The presence of sugars or reaction products (such as furfural and hydroxy-methyl-furfural), by the Maillard reaction, can accelerate the degradation of anthocyanins; they can be condensed to form browning pigments. This reaction is highly dependent on the temperature and the presence of oxygen (Von Elbe \& Schwartz, 1996). Coloring of Roselle calyces extracts is mainly due to anthocyanins, responsible for the red color and much of their antioxidant capacity (Tsai, Mcintosh, Pearce, Camden, \& Jordan, 2002; Tsai \& Huang, 2004). It has been reported higher antioxidant capacity in red than in white Roselle calyces (Christian \& Jackson, 2009). Thus, an intense red color of extracts suggests a higher content of these compounds. Extracts that had the highest anthocyanins content were obtained with 50\% ethanol, using an APS of $0.5 \mathrm{~mm}$, which showed a darker red coloration. A positive correlation was observed between anthocyanins and purity for alcoholic extracts obtained with an APS of $0.5 \mathrm{~mm}$ (Figure 3). 


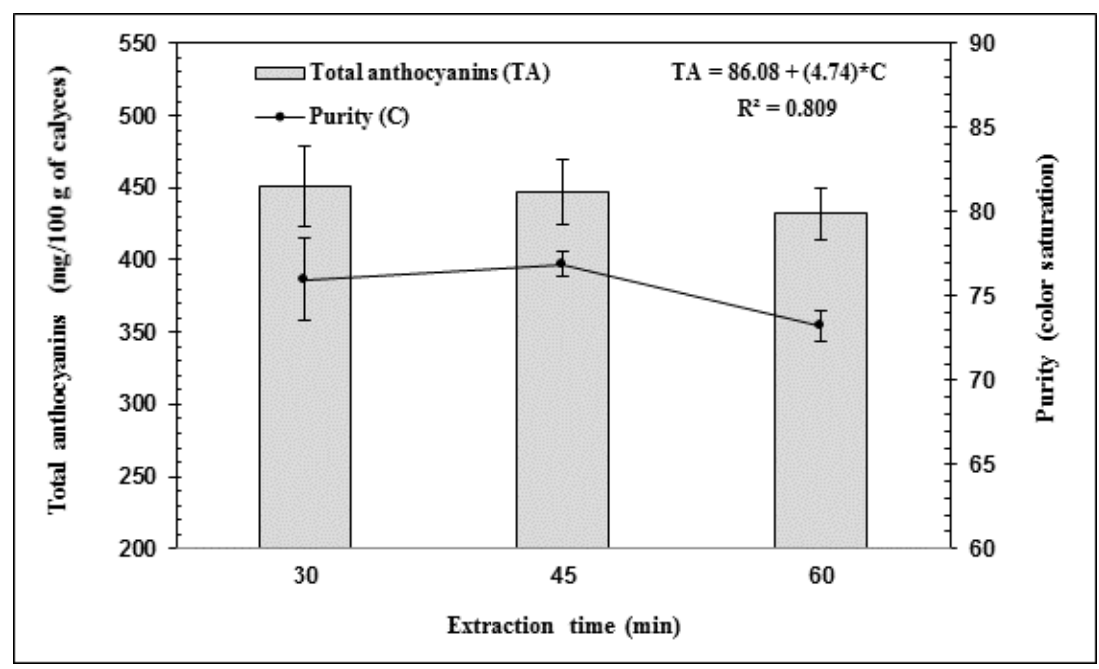

Figure 3. Relationship between anthocyanins concentration and purity of alcoholic extracts obtained at $50^{\circ} \mathrm{C}$ using an average particle size of $0.5 \mathrm{~mm}$. Values represent the mean \pm standard deviation $(\mathrm{n}=3)$

\subsubsection{Total Phenolics}

The total phenols content showed similar behavior as the total anthocyanins content (Table 4) regarding to the independent variables. The average particle size, solvent type, and extraction time showed a statistically significant difference $(\mathrm{p} \leq 0.05)$. In general, in Table 4 is shownthat the alcoholic extracts have higher phenols content in comparison to the aqueous and acid extracts. The extraction time of 30 min showed better performance in the amount of extraction of total phenols than 45 and $60 \mathrm{~min}$; however, no correlation $\left(\mathrm{R}^{2}=\right.$ 0.625) was observed within the total phenols content. Additionally, a positive correlation was observed between phenols and anthocyanins content (Figure 4).

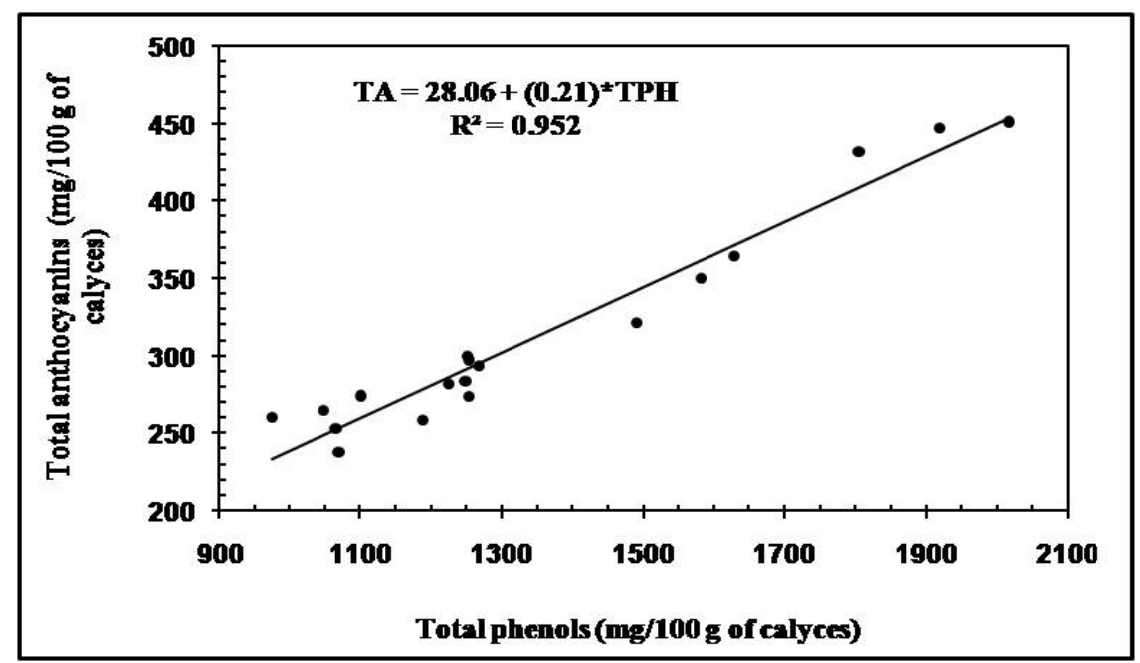

Figure 4. Correlation between the concentration of anthocyanins (TA) and total phenols (TPH). Values represent the mean of six analyses

Abou-Arab et al. (2011) reported a concentration of anthocyanins (as cyanidin-3-glycoside) and total phenols (as Gallic acid) of $1063 \pm 3.0$ and $4172 \pm 200 \mathrm{mg} / 100 \mathrm{~g}$ of calyces, respectively, using a $\%$ citric acid solution as the extracting agent. When using distilled water they reported $545.39 \pm 2.0$ and $3839 \pm 200 \mathrm{mg} / 100 \mathrm{~g}$ of calyces of anthocyanins and phenols, respectively. Similar results were reported by Chumsri et al. (2008); they used a ratio of Roselle calyces:water of $1: 10$ at $50{ }^{\circ} \mathrm{C}$ for $30 \mathrm{~min}$. The contents of anthocyanins and total phenols were $502.33 \pm 0.52$ and $4300 \pm 97 \mathrm{mg} / 100 \mathrm{~g}$ calyces, respectively.

Mohd-Esa, Shin-Hern, Ismail, and Lye-Yee (2010) reported a total phenols content of $185.0 \pm 10 \mathrm{mg}$ Gallic 
acid/100 g of calyces for water extracts as well as $291.0 \pm 7 \mathrm{mg}$ Gallic acid/100 g calyces for $80 \%$ ethanol (v/v) extracts. The extracts were obtained by stirring; they mixed one gram of Roselle in one L of solvent for 2 hours at room temperature. Salazar-González et al. (2012), who used the same Roselle variety, as the one used in this study, reported an anthocyanins concentration of $209 \pm 21 \mathrm{mg} / 100 \mathrm{~g}$ of Roselle and a total phenolics content of $2415 \pm 96 \mathrm{mg} / 100 \mathrm{~g}$ of Roselle in 50:50 \% (v/v) ethanol:water extracts. Differences in results from this work and other studies are mainly due to the variety of Roselle, as well as sample:solvent ratio, extracting method, and type of solvent. It is noteworthy that in the reportscited above, researchersdo not mention the average particle size; they only allude the use a ground Roselle calyces.

Cissé et al. (2012) evaluated the solid-liquid extraction process for the production of anthocyanins from Roselle. They reported that the calyces: solvent ratio and particle size were the main factors affecting the efficiency of extraction of anthocyanins. The maximum yield $(88 \%)$ of anthocyanins was achieved using a Roselle calyces:solvent ratio of $1: 25$, stirring for 10 hours at $25^{\circ} \mathrm{C}$. However, using an average particle size of $0.15 \mathrm{~mm}$, the extraction time was reduced to approximately $10 \mathrm{~min}$ to obtain a yield $63 \%$.

According to the results obtained in this study, the average particle size is an important variable to be considered in the extraction of anthocyanins and total phenols. The extraction time and type of solvent significantly influenced $(\mathrm{p} \leq 0.05)$ the response variables. Better quantities of phenolics were obtained using a 50:50\% ethanol-water ratioand an ET of $30 \mathrm{~min}$. Jokić et al. (2010) evaluated the influence of water and ethanol at different concentrations $(50,60,70,80 \%)$, temperatures $\left(25,40,50,60,70,80^{\circ} \mathrm{C}\right)$, and extraction times $(5,10$, $15,20,30,40,60,90,120 \mathrm{~min})$ on the extraction of total phenols of soybeans, Ika variety, using an average particle size of $0.459 \mathrm{~mm}$ and a liquid-solid ratio of $20 \mathrm{~mL} / \mathrm{g}$. The total phenols concentration increased as temperature increased. Grater total phenols concentration was obtained using $50 \%$ ethanol at $80{ }^{\circ} \mathrm{C}$ for 120 min of extraction.

Dent et al. (2013) conducted a study for evaluating the effect of type of solvent (30,50, and $70 \%$ ethanol:water, acetone-water solutions and distilled water), temperature $\left(60\right.$ and $\left.90{ }^{\circ} \mathrm{C}\right)$, and time $(30,60$, and $90 \mathrm{~min})$ on the extraction of phenolic compounds from sage (Salvia officinalis L). They reported that $30 \%$ ethanol or acetone were the most efficient extracting agents of phenolic compounds for sage calyces at $60{ }^{\circ} \mathrm{C}$ for $30 \mathrm{~min}$. As noted, the conditions for extraction of bioactive compounds (mainly anthocyanins and phenolic compounds) largely depend on solvent type, sample type, and particle size. An important aspect to note is that the binary solvent systems are more efficient for the extraction of these compounds than mono-solvent systems, very probably due to their relative polarity.

\section{Conclusions}

This work demonstrates the importance of the average particle size, type of solvent and extraction time on the extraction of bioactive compounds such as anthocyanins and total phenols of Roselle calyces. The extraction at $50{ }^{\circ} \mathrm{C}$ in the range of 30 to $45 \mathrm{~min}$ did not significantly reduce the content of anthocyanins and total phenols. The use of $50 \%$ ethanol:water and an average particle size of $0.5 \mathrm{~mm}$ significantly improved yields of bioactive compounds from Roselle. Roselle extracts obtained with these conditions represent an important source of these bioactive compounds, which could be used as ingredients in the food industry.

\section{Acknowledgments}

S. Cid-Ortega thanks to PROMEP (Program for the Educational Professional Improvement) and UTIM (Universidad Tecnológica de Izúcar Matamoros, Puebla, Mexico) for the scholarship granted to complete his doctoral studies.

\section{References}

Abou-Arab, A. A., Abu-Aalem, F. M., \& Abou-Arab, E. A. (2011). Physico-chemical properties of natural pigments (anthocyanin) extracted from Roselle calyces (Hibiscus sabdariffa). Journal of American Science, 7(7), 445-456.

Akim, A., Chooi, L. L., Rahmat, A., \& Amiruddin, Z. Z. (2011). Antioxidant and anti-proliferative activities of Roselle juice on Caov-3, MCF-7, MDA-MB-231 and HeLa cancer cell lines. African Journal of Pharmacy and Pharmacology, 5(7), 957-965. http://dx.doi.org/10.5897/AJPP11.207

Ali, B. H., Wabel, N. A., \& Blunden, G. (2005). Phytochemical, pharmacological and toxicological aspects of Hibiscus sabdariffa L.: A review. Phytotherapy Research, 19(5), 369-375. http://dx.doi.org/10.1002/ptr.1628

AOAC. (1980). Official Methods of Analysis (13th ed.). Association of Official Analytical Chemists. Inc. 
Washington, D.C., USA.

AOAC. (1995). Official Methods of Analysis (14th ed.). Association of Official Analytical Chemists. Inc. Washington, D.C., USA.

Cañigueral, S. (2003). Plantas medicinales y drogas vegetales. Offarm - Farmacia y Sociedad (Spain), 22(5), 185-186.

Christian, K. R., \& Jackson, J. C. (2009). Changes in total phenolic and monomeric anthocyanin composition and antioxidant activity of three varieties of sorrel (Hibiscus sabdariffa) during maturity. Journal of Food Composition and Analysis, 22, 663-667. http://dx.doi.org/10.1016/j.jfca.2009.05.007

Chumsri, P., Sirichote, A., \& Itharat, A. (2008). Studies on the optimum conditions for the extraction and concentration of Roselle (Hibiscus sabdariffa Linn.) extract. Songklanakarin Journal of Science and Technology, 30(1), 133-139.

Cissé, M., Vaillant, F., Acosta, O., Dhuique-Mayer, C. Y., \& Dornier, M. (2009). Thermal degradation kinetics of anthocyanins from blood orange, blackberry, and Roselle using the Arrhenius, Eyring, and Ball models. Journal of Agricultural and Food Chemistry, 57(14), 6285-6291. http://dx.doi.org/10.1021/jf900836b

Cissé, M., Bohuonb, P., Sambea, F., Kanea, C., Sakhoa, M., \& Dornier, M. (2012). Aqueous extraction of anthocyanins from Hibiscus sabdariffa: experimental kinetics and modeling. Journal of Food Engineering, 109(1), 16-21. http://dx.doi.org/10.1016/j.jfoodeng.2011.10.012

Dai, J., \& Mumper, R. J. (2010). Plant phenolics: extraction, analysis and their antioxidant and anticancer properties. Molecules, 15(10), 7313-7352. http://dx.doi.org/10.3390/molecules 15107313

Decagon Devices Inc. (2008). AquaLab water activity meter. Operator's manual for series 4TE, 4TEV, DUO (Version 7). Pullman, WA, Decagon Devices Inc.

Dent, M., Dragović-Uzelac, V., Penić, M., Brnčić, M., Bosiljkov, T., \& Levaj, B. (2013). The effect of extraction solvents, temperature and time on the composition and mass fraction of polyphenols in Dalmatian wild sage (Salvia officinalis L.) extracts. Food Technology and Biotechnology, 51(1), 84-91.

Fakeye, T. (2008). Toxicity and immunomodulatory activity of fractions of Hibiscus sabdariffa Linn (family malvaceae) in animal models. African Journal of Traditional, Complementary and Alternative medicines, 5(4), 394-398.

Galicia-Flores, L. A., Salinas-Moreno, Y., Espinoza-García, B. M., \& Sánchez-Feria, C. (2008). Caracterización fisicoquímica y actividad antioxidante de extractos de Jamaica (Hibiscus sabdariffa L.) nacional e importada. Revista Chapingo Serie Horticultura (México), 14(2), 121-129.

Gartaula, G. Y., \& Karki, D. B. (2010). Optimization of extraction of anthocyanins from Roselle (Hibiscus Sabdariffa var. sabdariffa) in aqueous medium. Journal of Food Science and Technology Nepal, 6, 69-72.

Gee, G. W., \& Or, D. (2002). Particle-size analysis. In J. H. Dane \& G. C. Topp (Eds.), Methods of soil analysis (pp. 255-293). Madison, WI: Soil Science Society of America, Inc.

Guerrero-Beltrán, J. A., Jiménez-Munguía, M. T., Welti-Chanes, J., \& Barbosa-Cánovas, G. V. (2009). Particle size distribution functions for food powders. In M. E. Sosa-Morales \& J. F. Vélez-Ruiz (Eds.), Food Processing and Engineering Topics (pp. 59-85). New York, USA: Nova Publishers Inc.

Herrera-Arellano, A., Miranda-Sánchez, J., \& Avila-Castro, P. (2007). Clinical effects produced by a standardized herbal medicinal product of Hibiscus sabdariffa on patients with hypertension. A randomized, double-blind, lisinopril-controlled clinical trial. Planta Medica, 73(1), 6-12. http://dx.doi.org/10.1055/s-2006-957065

Jokić, S., Velić, D., Bilić, M., Bucić-Kojić, A., Planinić, M., \& Tomas, S. (2010). Modelling of the process of solid-liquid extraction of total polyphenols from soybeans.Czech Journal of Food Sciences, 28(3), 206-212.

Josiah, S., Omotuyi, O., Oluyemi, K., Ezea, I., Uhunmwangho, E., Nwangwu, S., Oyesola, O., \& Njoya, H. (2010). Protective role of aqueous extract of Hibiscus sabdariffa (calyx) against potassium bromate induced tissue damage in Wistar rats. African Journal of Biotechnology, 9(21), 3218-3222. http://dx.doi.org/10.5897/AJB10.1119

Juliani, H. R., Welch, C. R., Wu, Q., Diouf, B., Malainy, D., \& Simon, J. E. (2009). Chemistry and quality of hibiscus (Hibiscus sabdariffa) for developing the natural-product industry in Senegal. Journal of Food Science, 74(2), 113-121. http://dx.doi.org/10.1111/j.1750-3841.2009.01076.x 
Lee, J., Durst, R. W., \& Wrolstad, R. E. (2005). Total monomeric anthocyanin pigment content of fruit juices, beverages, natural colorants, and wines by the $\mathrm{pH}$ differential method: collaborative study. Journal of AOAC International, 88(5), 1269-1278.

Mohd-Esa, N., Shin-Hern, F., Ismail, A., \& Lye-Yee, C. (2010). Antioxidant activity in different parts of Roselle (Hibiscus sabdariffa L.) extracts and potential exploitation of the seeds. Food Chemistry, 122, 1055-1060. http://dx.doi.org/10.1016/j.foodchem.2010.03.074

NMX-F-317-S-1978. (1978). Norma mexicana. Determinación de pH en alimentos. [Mexican standard. Determination of $\mathrm{pH}$ in foods]. México, D. F.: Dirección General de Normas. Retrieved from http://200.77.231.100/work/normas/nmx/1978/nmx-f-317-s-1978.pdf

NMX-FF-015-1982. (1982). Norma mexicana. Productos alimenticios no industrializados, para uso humano fruta fresca - determinación de sólidos solubles totales. [Mexican standard. Non industrialized food products for human use - Fresh fruit - Determination of total soluble solids]. México, D. F.: Dirección General de Normas. Retrieved from http://200.77.231.100/work/normas/nmx/1982/nmx-ff-015-1982.pdf

NMX-FF-115-SCFI-2010. (2010). Norma mexicana. Productos agrícolas destinados para consumo humano - flor (cáliz) de Jamaica (Hibiscus sabdariffa L.) - especificaciones y métodos de prueba. [Mexican standard. Agricultural products for human consumption calyx of Roselle (Hibiscus sabdariffa L.) - Specifications and assays]. México, D. F.: Dirección General de Normas. Retrieved from http://200.77.231.100/work/normas/nmx/2010/nmx-ff-115-scfi-2010.pdf

NOM-116-SSA1-1994. (1994). Norma oficial mexicana. Determinación de humedad en alimentos por tratamiento térmico. Método por arena o gasa. [Mexican standard. Determination of moisture in foods by heat treatment. Method for sand or gauze]. México, D. F.: Dirección General de Normas.Retrieved from http://www.salud.gob.mx/unidades/cdi/nom/116ssa14.html

O’Hagan, P., Hasapidis, K., Coder, A., Helsing, H., \& Pokrajac, G. (2005). Particle Size Analysis of Food Powders. In C. Onwulata (Ed.), Encapsulated and Powdered Foods (pp. 215-245). Boca Raton, FL, USA: CRC Press Taylor \& Francis Group.

Ojeda, D., Jiménez-Ferrer, E., Zamilpab, A., Herrera-Arellano, A., Tortoriello, J., \& Alvarez, L. (2010). Inhibition of angiotensin convertin enzyme (ACE) activity by the anthocyanins delphinidin- and cyanidin-3-O-sambubiosides from Hibiscus sabdariffa. Journal of Ethnopharmacology, 127, 7-10. http://dx.doi.org/10.1016/j.jep.2009.09.059

Salazar-González, C., Vergara-Balderas, F. T., Ortega-Regules, A. E., \& Guerrero-Beltrán, J. A. (2012). Antioxidant properties and color of Hibiscus sabdariffa extracts. Ciencia e Investigación Agraria, 39(1), 79-90. http://dx.doi.org/10.4067/S0718-16202012000100006

Singleton, V. L., \& Rossi, J. A. (1965). Colorimetry of total phenolics with phosphomolybdic-phosphotungstic acid reagents. American Journal of Enology and Viticulture, 16(3), 144-158.

Sini, J. M., Umar, I. A., \& Inuwa, H. M. (2011). The beneficial effect of extract of Hibiscus sabdariffa calyces in alloxan-diabetic rats: hypoglycaemic and hypolipidaemic activities. Journal of Medicinal Plants Research, 5(11), 2182-2186.

Suliman, A. M. A., Ali, O. A., Idriss-Sharaf, E. A. A., \& Abdualrahman, M. A. Y. (2011). A comparative study on red and white karkade (Hibiscus sabdariffa L.) calyces, extracts and their products. Pakistan Journal of Nutrition, 10(7), 680-683. http://dx.doi.org/10.3923/pjn.2011.680.683

Tonon, R. V., Brabet, C., \& Hubinger, M. D. (2010). Anthocyanin stability and antioxidant activity of spray-dried açai (Euterpe oleracea Mart.) juice produced with different carrier agents. Food Research International, 43, 907-914.http://dx.doi.org/10.1016/j.foodres.2009.12.013

Tsai, P.-J., McIntosh, J., Pearce, P., Camden, B., \& Jordan, B. R. (2002). Anthocyanin and antioxidant capacity in Roselle (Hibiscus sabdariffa $\quad$ L.) extract. Food Research International, 35, 351-356. http://dx.doi.org/10.1016/S0963-9969(01)00129-6

Tsai, P. J., \& Huang, H. P. (2004). Effect of polymerization on the antioxidant capacity of anthocyanins in Roselle. Food Research International, 37, 313-318.http://dx.doi.org/10.1016/j.foodres.2003.12.007

Ubani, C. S., Joshua, P. E., \& Oraeki, A. N. (2010). Influence of aqueous extract of Hibiscus sabdariffa calyces on lipid profile of phenobarbitone induces Wistar albino rats. Journal of Pharmacy Research, 3(2), 319-324.

Von Elbe, J. H., \& Schwartz, S. J. (1996). Colorants. In Fennema, O. R. (ed.), Food Chemistry (3rd ed.). New 
York, Marcel Dekker.

\section{Copyrights}

Copyright for this article is retained by the author(s), with first publication rights granted to the journal.

This is an open-access article distributed under the terms and conditions of the Creative Commons Attribution license (http://creativecommons.org/licenses/by/3.0/). 